\title{
Anakinra: a silver lining in COVID-19?
}

\author{
Rahul Gupta(D)
}

Dear Editor,

In the recent review article Blocking IL-1 to prevent respiratory failure in COVID-19 by Dr. Veerdonk and Dr. Netea [1], they have implicated the importance IL-1 signaling in severe COVID-19 pathogenesis and proposed anakinra as a therapeutic intervention. I would like to humbly add some views to it; in severe COVID-19 pathology, higher amounts of microthrombi deposition can lead to the blockage in the capillaries and arteries culminating in hypoxic condition and ensuing necrosis-like events. In fact, autopsy studies have reported necrotic events of lung pneumocytes in severe COVID-19 patients [2]. Also, high serum levels of receptor-interacting protein kinase 3 (RIPK-3) in severe patients corroborate necroptosis too [3].

The damage-associated molecular pattern IL- $1 \alpha$ (alarmin) liberated by necrotizing lung epithelial cells could be one of the initial cytokine produced during COVID19 pathogenesis [4]. IL- $1 \alpha$ by further engagement to IL$1 \mathrm{R}$ lead to the production of an array of chemokines and cytokines [4]. IL-1 $\beta$, IL-6, TNF- $\alpha$, GM-CSF, IL-17, CXC chemokines, CCL chemokines, etc. are some of the few upregulated cytokines/chemokines in severe COVID-19 responsible for exacerbating the lung pathophysiology by fueling up infiltration of macrophages/neutrophils, hypercoagulability, and fibrosis phenomena [1]. Interestingly, IL-17, IL-6, GM-CSF, HIF- $\alpha$, and CXC chemokines are regulated by IL- $1 \beta$. The hypercoagulability with thromboembolic indications in severe patients is attributed to platelet activation and platelet monocyte aggregation, leading to the induction of tissue factor (TF) [5]. Also, IL-1 $\beta$ is known to positively regulate TF expression. Taming the cytokine storm can be an effective management strategy and IL-1 signaling might play a crucial role in the pathogenesis of the disease. It could be initial necrosis liberating IL- $1 \alpha$, which drives

\footnotetext{
Correspondence: rbiochem@gmail.com
}

Independent Researcher, India

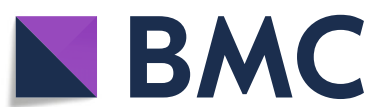

amplifying inflammation loop eventually leading to inflammasome-dependent pyroptosis determining the severity of the disease. Anakinra (IL- $1 \alpha$ and IL-1 $\beta$ blocker) has shown greatly reduced mortality, need for invasive mechanical ventilation, and bettering oxygenation status in severe COVID-19 patients in smaller clinical studies [1]. Hence, anakinra might be effective in managing the severe pandemic state; more so, it is a well-tolerated molecule with no adverse effects. Larger controlled clinical trials with anakinra are much warranted to test the efficacy unequivocally.

\section{Acknowledgements \\ Rahul is very grateful to Dr. Kate Fitzgerald and Dr. Doug Golenbock (UMASSMED) for the initial insightful discussion.}

\section{Author's contributions}

Rahul did the literature survey and wrote the manuscript. The author read and approved the final manuscript.

\section{Funding}

The study has not received any funding as yet.

\section{Availability of data and materials}

Literature survey

\section{Ethics approval and consent to participate}

Not applicable

\section{Consent for publication}

Yes.

\section{Competing interests}

I do not have any competing interests.

Received: 10 September 2020 Accepted: 27 September 2020 Published online: 06 October 2020

\section{References}

1. van de Veerdonk FL, Netea MG. Blocking IL-1 to prevent respiratory failure in COVID-19. Crit Care. 2020. https://doi.org/10.1186/s13054-020-03166-0.

2. Carsana L, Sonzogni A, Nasr A, Rossi RS, Pellegrinelli A, Zerbi P, et al. Pulmonary post-mortem findings in a series of COVID-19 cases from northern Italy: a two-centre descriptive study. Lancet Infect Dis. 2020. https://doi.org/10.1016/S1473-3099(20)30434-5.

3. Nakamura H, Kinjo T, Arakaki W, Miyagi K, Tateyama M, Fujita J. Serum levels of receptor-interacting protein kinase-3 in patients with COVID-19. Crit Care. 2020. https://doi.org/10.1186/s13054-020-03209-6.

(c) The Author(s). 2020 Open Access This article is licensed under a Creative Commons Attribution 4.0 International License, which permits use, sharing, adaptation, distribution and reproduction in any medium or format, as long as you give appropriate credit to the original author(s) and the source, provide a link to the Creative Commons licence, and indicate if changes were made. The images or other third party material in this article are included in the article's Creative Commons licence, unless indicated otherwise in a credit line to the material. If material is not included in the article's Creative Commons licence and your intended use is not permitted by statutory regulation or exceeds the permitted use, you will need to obtain permission directly from the copyright holder. To view a copy of this licence, visit http://creativecommons.org/licenses/by/4.0/. The Creative Commons Public Domain Dedication waiver (http://creativecommons.org/publicdomain/zero/1.0/) applies to the data made available in this article, unless otherwise stated in a credit line to the data. 
4. Di Paulo NC, Shayakhmetov DM. Interleukin 1a and the inflammatory process. Nat Immunol. 2016;17:906-13.

5. Hottz ED, Azevedo-Quintanilha IG, Palhinha L, Teixeira L, Barreto EA, Pao CRR, et al. Platelet activation and platelet-monocyte aggregates formation trigger tissue factor expression in severe COVID-19 patients. Blood. 2020. https://doi.org/10.1182/blood.2020007252

\section{Publisher's Note}

Springer Nature remains neutral with regard to jurisdictional claims in published maps and institutional affiliations. 